Portland State University

PDXScholar

$1-2014$

\title{
Impacts of Fire and Climate Change on Long-Term Nitrogen Availability and Forest Productivity in the New Jersey Pine Barrens
}

Melissa S. Lucash

Portland State University, lucash@pdx.edu

Robert M. Scheller

Portland State University, rmschell@pdx.edu

Alec M. Kretchun

Portland State University

Kenneth L. Clark

USDA Forest Service

John Hom

USDA Forest Service

Follow this and additional works at: https://pdxscholar.library.pdx.edu/esm_fac

Part of the Biodiversity Commons, Environmental Indicators and Impact Assessment Commons, and the Forest Management Commons

Let us know how access to this document benefits you.

\section{Citation Details}

Lucash M., Scheller, R.M, Kretchun, A.M., Clark, K.L., Hom, J., Impacts of fire and climate change on longterm nitrogen availability and forest productivity in the New Jersey Pine Barrens. Can. J. For. Res., 2014, 44.

This Article is brought to you for free and open access. It has been accepted for inclusion in Environmental Science and Management Faculty Publications and Presentations by an authorized administrator of PDXScholar. Please contact us if we can make this document more accessible: pdxscholar@pdx.edu. 


\title{
Impacts of fire and climate change on long-term nitrogen availability and forest productivity in the New Jersey Pine Barrens
}

\author{
Melissa S. Lucash, Robert M. Scheller, Alec M. Kretchun, Kenneth L. Clark, and John Hom
}

\begin{abstract}
Increased wildfires and temperatures due to climate change are expected to have profound effects on forest productivity and nitrogen $(\mathrm{N})$ cycling. Forecasts about how wildfire and climate change will affect forests seldom consider $\mathrm{N}$ availability, which may limit forest response to climate change, particularly in fire-prone landscapes. The overall objective of this study was to examine how wildfire and climate change affect long-term mineral $\mathrm{N}$ availability in a fire-prone landscape. We employed a commonly used landscape simulation model (LANDIS-II) in the New Jersey Pine Barrens, a landscape characterized by frequent small fires and fire-resilient vegetation. We found that fire had little effect on mineral $\mathrm{N}$, whereas climate change and fire together reduced mineral $\mathrm{N}$ by the end of the century. Though $\mathrm{N}$ initially limited forest productivity, mineral $\mathrm{N}$ was no longer limiting after 50 years. Our results suggest that mineral $\mathrm{N}$ is resilient to fire under our current climate but not under climate change. Also, predictions that do not consider $\mathrm{N}$ limitation may underestimate short-term but not long-term productivity responses to climate change. Together these results illustrate the importance of including $\mathrm{N}$ dynamics when simulating the effects of climate change on forest productivity, particularly in fire-prone regions such as the New Jersey Pine Barrens.
\end{abstract}

Key words: Century, forest simulation model, LANDIS-II, nitrogen cycle.

Résumé : On s'attend à ce que l'augmentation des températures et des feux de forêt due aux changements climatiques aient de sérieux impacts sur la productivité des forêts et le recyclage de l'azote $(\mathrm{N})$. Les prévisions concernant les impacts des feux et des changements climatiques sur les forêts tiennent rarement compte de la disponibilité de $\mathrm{N}$, laquelle peut limiter la réaction de la forêt aux changements climatiques, particulièrement dans les paysages sujets aux feux. L'objectif général de cette étude consistait à examiner comment les feux de forêt et les changements climatiques affectent la disponibilité à long terme de $\mathrm{N}$ minéral dans un paysage sujet aux feux. Nous avons utilisé un modèle de simulation du paysage d'usage courant (LANDIS-II) dans les pinèdes de la plaine côtière du New Jersey, un paysage caractérisé par de fréquents feux de faible intensité et une végétation qui supporte bien les feux. Nous avons trouvé que le feu avait peu d'effet sur $\mathrm{N}$ minéral tandis que les changements climatiques couplés aux feux réduisaient la disponibilité de $\mathrm{N}$ vers la fin du siècle. Même si initialement $\mathrm{N}$ limitait la productivité de la forêt, $\mathrm{N}$ minéral n'était plus un facteur limitant après 50 ans. Nos résultats indiquent que $\mathrm{N}$ minéral n'est pas affecté par les feux dans les conditions climatiques actuelles mais qu'il le sera dans les conditions associées aux changements climatiques. De plus, les prédictions qui ne tiennent pas compte de la disponibilité de $\mathrm{N}$ pourraient sous-estimer les réactions de la productivité aux changements climatiques à court mais non à long terme. Globalement, ces résultats illustrent l'importance d'inclure la dynamique de $\mathrm{N}$ lorsqu'on simule les effets des changements climatiques sur la productivité des forêts, particulièrement dans les régions sujettes aux feux comme c'est le cas dans les pinèdes de la plaine côtière du New Jersey. [Traduit par la Rédaction]

Mots-clés : Century, modèle de simulation de la forêt, LANDIS-II, cycle de l'azote.

\section{Introduction}

Wildfire is a common, episodic disturbance that has a large impact on forest productivity and nutrient cycling. Since the early 1900 s, humans have significantly altered the fire regime through an effective fire suppression campaign (Stephens and Ruth 2005) that has substantially reduced the overall area burned (Stephens et al. 2007). Over the last several decades, however, the frequency of severe wildfires and the amount of area burned has increased, driven by changes in the composition and structure of forests (ironically due to fire suppression) and alterations in the climate (Westerling et al. 2006). These rising trends in wildfire activity are predicted to continue into the future, exacerbated by rising temperatures associated with climate change (Scholze et al. 2006). This has prompted concern about wildfire impacts on nitrogen (N) cycling and the potential ability of available $\mathrm{N}$ to sustain longterm forest productivity given the changing climate.

Wildfires have dramatic effects on the nitrogen budget of forests. Because $\mathrm{N}$ has a low volatilization temperature, large amounts of total nitrogen from burned trees and surficial litter are lost to the atmosphere during a fire. Even though this causes an initial and substantial decline in total ecosystem $\mathrm{N}$, the longterm (decadal to century) effects of fire on $\mathrm{N}$ are more complex, particularly for mineral $\mathrm{N}$. After a fire, there is a pulse of mineral $\mathrm{N}$ due to the breakdown of organic $\mathrm{N}$ in ash (Raison 1979) and litter (White et al. 1973) and decomposition of the remaining coarse woody debris (Hafner and Groffman 2005). This short-term (<2 years) pulse of mineral $\mathrm{N}$ may, in turn, stimulate $\mathrm{N}$ uptake and microbial immobilization, causing a long-term decline in $\mathrm{N}$ availability (Durán et al. 2009). Mineral N is also indirectly affected by

Received 17 September 2013. Accepted 21 December 2013.

M.S. Lucash, R.M. Scheller, and A.M. Kretchun. Department of Environmental Science and Management, Portland State University, Portland, OR 97201, USA.

K.L. Clark. USDA Forest Service, Silas Little Experimental Forest, 501 Four Mile Road, New Lisbon, NJ 08064, USA.

J. Hom. USDA Forest Service, Northern Research Station, 11 Campus Blvd., Suite 200, Newtown Square, PA 19073, USA

Corresponding author: Melissa S. Lucash (e-mail: lucash@pdx.edu). 
fire, because fire can cause long-term changes in $\mathrm{N}$ stocks, species composition, and fire frequency. Several studies have shown that fire decreases mineral N over the long term (Durán et al. 2009), as fire increases N volatilization (DeBell and Ralston 1970), erosion (Debano and Conrad 1978), and leaching (Stephan et al. 2012).

Mineral $\mathrm{N}$ is also affected by temperature and precipitation; thus climate change will likely affect mineral N. Predicting how wildfire and climate change will affect $\mathrm{N}$ is difficult, because the mineral $\mathrm{N}$ pool reflects the integration of multiple fluxes (e.g., $\mathrm{N}$ uptake, leaching, mineralization), which may be differentially affected by temperature, precipitation, and fire. For example, $\mathrm{N}$ mineralization rates are directly correlated with temperature (Rustad et al. 2001); therefore, mineral $\mathrm{N}$ may increase with climate change. However, tree growth rates (and therefore $\mathrm{N}$ uptake) may increase with rising temperature, causing a decline in mineral $\mathrm{N}$. In regions where precipitation is expected to increase, mineral $\mathrm{N}$ may decline due to higher $\mathrm{N}$ leaching and uptake. Finally, climate change may also alter species composition (Iverson and Prasad 1998), which may alter $\mathrm{N}$ availability directly by changing decomposition rates or indirectly through changes in litter quantity and quality.

Forecasting how fire and climate change will affect long-term $\mathrm{N}$ cycling and productivity is particularly important in nutrientpoor, N-limited soils. At a global scale, the literature supports both concerns over long-term limitations of mineral $\mathrm{N}$ (Hungate et al. 2003) and suggestions that the importance of $\mathrm{N}$ limitation may decline over time as forest productivity becomes less coupled to $\mathrm{N}$ deposition (Pan et al. 2009). Despite the importance of this topic, no studies have simulated future trends in mineral $\mathrm{N}$ and projected how it may limit the long-term growth of forests given changes in wildfire regimes and the climate.

The overall objective of this study was to simulate long-term mineral $\mathrm{N}$ availability in the New Jersey Pine Barrens (NJPB), a nutrient-poor, fire-prone landscape in the northeastern United States (US). We assessed three main forest types (uplands, wetlands, and pine plains) by employing a widely used landscape model (LANDIS-II; Scheller et al. 2007). We restricted our interpretation to mineral $\mathrm{N}$ (i.e., nitrate and ammonium), as organic $\mathrm{N}$ is probably a small fraction of $\mathrm{N}$ uptake by trees in ecosystems with high mineralization rates (Vadeboncoeur et al. 2012). We also tested whether the growth stimulation caused by climate change (i.e., temperature and precipitation) will be limited by N. Though $\mathrm{CO}_{2}$ emissions influence the climate change projections that we used, we did not simulate the impacts of $\mathrm{CO}_{2}$ on mineral $\mathrm{N}$ as it is not currently incorporated into the model (LANDIS-II, Century extension) and has already been discussed elsewhere (Luo et al. 2004). Specifically, we tested two hypotheses. (1) Fire will decrease mineral $\mathrm{N}$ as shown in other studies (Durán et al. 2009). We expect that declines in mineral $\mathrm{N}$ will be greater in the uplands than in the wetlands as fire is more prevalent in the uplands. (2) Climate change (in concert with fire) will decrease mineral $\mathrm{N}$. We expect that climate change will stimulate plant growth and $\mathrm{N}$ uptake, which will deplete the pool of mineral $\mathrm{N}$, ultimately leading to $\mathrm{N}$ limitation (Hungate et al. 2003).

\section{Materials and methods}

\section{Site description}

The NJPB in southern New Jersey is the largest intact forest landscape on the coastal plain of the northeastern US, comprising over 400000 ha (22\% of the land area in New Jersey; Fig. 1). Mean monthly temperatures are $0.3{ }^{\circ} \mathrm{C}$ in January and $24.3{ }^{\circ} \mathrm{C}$ in July; mean annual precipitation is $1159 \mathrm{~cm}$ (1980-2009; Office of the New Jersey State Climatologist, http:/(climate.rutgers.edu/stateclim/). Soils are derived from Lakewood and Sassafras (Tedrow 1986). Soils are sandy and acidic with a thin $(\sim 5-10 \mathrm{~cm})$ organic horizon and are low in exchangeable nutrients. The NJPB currently experiences about 934 wildfires per year (1991-2006; I. La Puma, un-
Fig. 1. Study area showing seven ecoregions delineated based on landcover type (uplands, wetland, and pine plains) and elevation (low, medium, and high) in the New Jersey Pine Barrens. (This figure is available in colour online.)

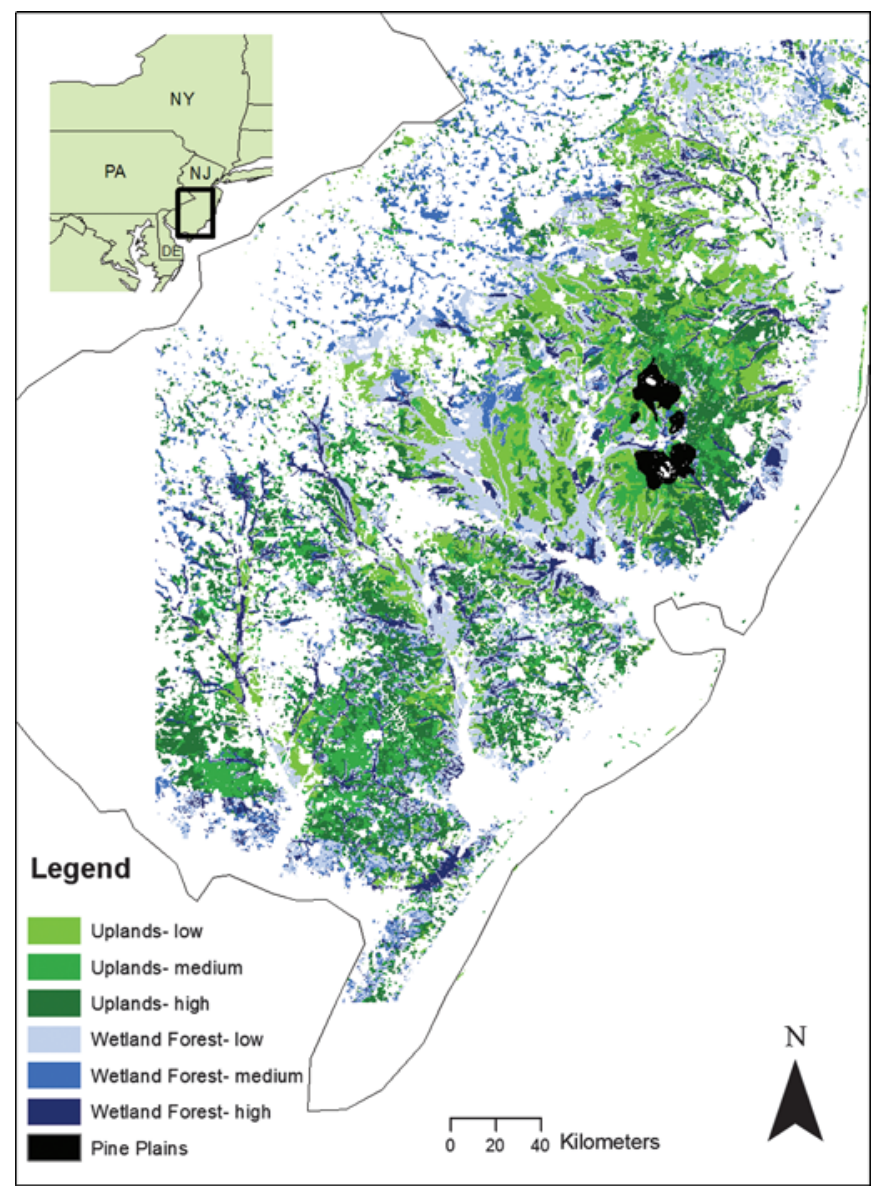

published data), significantly higher than during the precolonial period when there were only about 100 fires per year (Forman and Boerner 1981). Conversely, the total area burned annually (8000 ha) is much lower than during the precolonial period (22 000 ha).

Most of the fires occur in the uplands, which comprise $62 \%$ of the forested land in the NJPB. The uplands are dominated by either oak-pine forests with Quercus spp. overstory and scattered pitch pine (Pinus rigida Mill.) and shortleaf pine (Pinus echinata Mill.) or pine-oak forests dominated by pine with scattered oaks. The pine plains occupy a small proportion of the upland landscape $(\sim 3 \%)$ but are a unique forest community of stunted pitch pine found on xeric sites with deep, sandy soils. Lowland forested wetlands are also common across the landscape, comprising $33 \%$ of the forested land. The lowland forests are comprised of Atlantic white cedar (Chamaecyparis thyoides (L.) Britton, Sterns \& Poggenb.), red maple (Acer rubrum L.), swamp tupelo (Nyssa sylvatica Marshall), pitch pine, shortleaf pine, and other mesic-adapted hardwoods.

\section{Description of LANDIS-II}

We simulated the effects of fire and climate change on the NJPB using LANDIS-II. LANDIS-II simulates changes in tree and shrub composition as a function of disturbance, dispersal, and succession (Scheller et al. 2007). Because LANDIS models are optimized for large-scale spatial dynamics (Mladenoff 2004), trees are represented as species and age cohorts rather than individuals. Speciesage cohorts are dynamic within individual sites (i.e., grid cells), and there may be multiple species and cohorts within each site. Each 
site ( 1 ha) is assigned to an ecoregion, which has homogeneous climate and soil properties. Spatial interactions during succession and disturbance events (e.g., wildfire) are simulated and they overlap in time and space.

\section{Description of the Century Succession extension of LANDIS-II}

We used the Century Succession extension (ver. 3) of LANDIS-II to simulate tree establishment, forest succession, and $\mathrm{C}$ and $\mathrm{N}$ cycling (Fig. 2; Scheller et al. 2011a, 2012). This succession extension uses species-specific life history attributes and growth rates to model tree growth and regeneration, which helps determine successional changes in species composition. To calculate the pools and fluxes of $\mathrm{C}$ and $\mathrm{N}$, the extension simulates $\mathrm{N}$ deposition as a function of precipitation. The extension also simulates $\mathrm{N}$ leaching (dependent on precipitation, soil characteristics, and hydrologic flow rates) and denitrification, which is a function of available $\mathrm{N}$ (Scheller et al. 2012). The extension also simulates the internal cycling of $\mathrm{C}$ and $\mathrm{N}$ through the vegetation (leaf, wood, fine roots, and coarse roots by species and age), detritus (foliar, woody, fine roots, and coarse roots), and soil (fast, slow, and passive pools) (Scheller et al. 2011a, 2012). The decomposition of C and mineralization of $\mathrm{N}$ is calculated separately in each of the detrital and soil pools. Carbon and $\mathrm{N}$ fluxes are calculated using the algorithms specified in the extension's predecessor, the CENTURY soil model (ver. 4.5; Parton et al. 1983). Decomposition of detritus and soil organic matter is assumed to be microbially mediated and is a function of detrital inputs (e.g., leaf C-to-N ratios and lignin content) and soil conditions (e.g., soil moisture, temperature, and soil texture). For example, each soil and detrital pool respires a fixed percentage of carbon at each time step, with respiration increasing with sand content. The remaining detrital and soil pool then has a maximum decomposition rate, which is reduced by factors such as temperature and soil moisture. The Century Succession extension of LANDIS-II also includes feedbacks between vegetation and soil, accounting for $\mathrm{N}$ retranslocation (based on leaf and litter $\mathrm{N}$ ), $\mathrm{N}$ uptake as a function of $\mathrm{N}$ demand and mineral $\mathrm{N}$ availability, and the down-regulation of net primary production (NPP) when mineral N limits growth (Scheller et al. 2012). The extension also estimates above- and below-ground NPP, heterotrophic respiration (Rh), and net ecosystem exchange (NEE); NPP, $\mathrm{Rh}$, and NEE are all sensitive to changes in nitrogen and water availability. The extension runs at a monthly time step, though we summarized our results every 5 years.

\section{Parameterization and calibration of the Century Succession extension}

Although a detailed description of our procedures for parameterization of Century is found elsewhere (Scheller et al. 2008, 2012), here we briefly outline our procedures for gathering model inputs. ${ }^{1}$ The landscape was divided into seven ecoregions based on soil type and water holding capacity (low-, mid-, and highelevation uplands; low-, mid-, and high-elevation wetlands; pine plains) for all our simulations (Scheller et al. 2011b), but our results were aggregated into three broad land types (uplands, wetlands, and the pine plains) because the responses were similar within each land type. Nonforested areas (e.g., urban and agriculture areas) comprised $\sim 60 \%$ of the landscape and were inactive in all simulations, serving as fire breaks. Initial species composition for the simulations was derived from the U.S. Forest Service Forest Inventory and Analysis (FIA; http://fia.fs.fed.us/) data, though we restricted our analysis to 14 dominant tree species representing $90 \%$ of the cover in the NJPB (Scheller et al. 2008). First, we calculated the age of each tree based on diameter at breast height (DBH) and age relationships developed for the entire data set for all FIA plots in our landscape. Second, we transformed a land-cover map
Fig. 2. Pools (normal font) and fluxes (italics) of nitrogen are simulated in each cell in the Century Succession extension of LANDIS-II. This includes $\mathrm{N}$ inputs (deposition), outputs (leaching and denitrification), and internal fluxes (e.g., $\mathrm{N}$ uptake, $\mathrm{N}$ mineralization associated with decomposition, and $\mathrm{N}$ retranslocation from senescing leaves). Trees species and their ages are also tracked over time as they grow and die. Trees can re-establish through dispersal and vegetative reproduction across the spatially interactive landscape, allowing species composition to shift over time. Across the landscape, fire ignition rates and spread were simulated across the landscape using the Dynamic Fire and Dynamic Biomass Fuels Fuels extensions; fires may affect $\mathrm{N}$ and $\mathrm{C}$ cycling, along with species composition. Processes that are directly affected by climate change (i.e., temperature (temp.), precipitation (precip.), and moisture) are depicted using "bow tie" symbols, though climate change has the potential to indirectly affect all the processes depicted in this diagram. (This figure is available in colour online.)

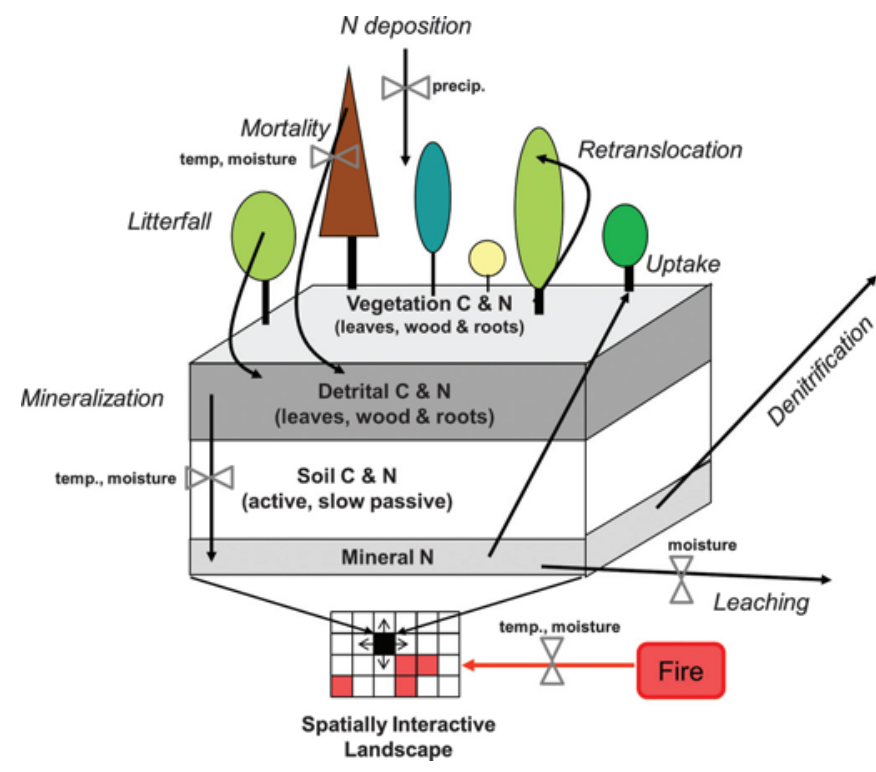

(30 m pixel size; Lathrop and Kaplan 2004) to generate an initial communities map composed of unique polygons, each associated with a forest type. Finally, for each polygon, we randomly assigned the attributes of an FIA plot from the suite of plots with that forest type to each polygon; this resulted in a map of tree species and age cohorts (details in Scheller et al. 2008). Species life history parameters were estimated based on values from the silvics manual (Burns and Honkala 1990) and expert knowledge of the NJPB (K. Clark; a full list of parameters is found in table 1 of Scheller et al. 2011b). Soils data, including water holding capacity and soil organic matter (SOM), were obtained from STATSGO (U.S. Department of Agriculture National Cartography and GIS Center 1994). Baseline climate data were generated from monthly averages for 1961-1990 from the U.S. Environmental Protection Agency Center for Exposure Assessment Modeling (http://www2.epa.gov/ exposure-assessment-models/meteorological-data). Our climate change scenario was derived from the Hadley Community Model 3 (HadCM3) general circulation model (GCM) (www.ipccdata.org/), which is a good predictor of climate change in the northeastern US (Ruosteenoja et al. 2003). Details about the methods that we used to downscale and validate our climate data at our site can be found in Scheller et al. (2012). A preliminary analysis indicated that a "low" emissions scenario (B1) showed little impact on aboveground net primary productivity (ANPP) and regenera-

${ }^{1}$ Supplementary data are available with the article through the journal Web site at http://nrcresearchpress.com/doi/suppl/10.1139/cjfr-2013-0383. 
tion relative to the baseline scenario, largely because of the moderating effect of the proximal Atlantic Ocean. Therefore, we used the A2 "high" emissions scenario (Intergovernmental Panel on Climate Change 2007) to highlight potential effects of climate change and to be consistent with previous research that described climate change impacts on C cycling in the NJPB (Scheller et al. 2012). Over the course of the 100-year simulation using the $\mathrm{A} 2$ scenario, maximum summer temperatures increased by $7.6^{\circ} \mathrm{C}$, while the minimum winter temperature increased by $5.1^{\circ} \mathrm{C}$. Precipitation increased by $30 \mathrm{~cm}$ over the 100 years, though it was more variable than temperature. The timing of precipitation shifted, with annual peaks shifting from August in 2000 to November in 2100 .

After model parameterization, we calibrated the carbon and nitrogen dynamics of the Century Succession extension using the procedures outlined in Scheller et al. (2011b, 2012). Briefly, we adjusted the $\mathrm{N}$ deposition slope and intercept parameters until the $\mathrm{N}$ deposition rates were within the range observed nearby $\left(\sim 1{\mathrm{~g} \mathrm{~N} \cdot \mathrm{m}^{-2} \text {.year }}^{-1}\right)$ and calibrated NPP using site-level estimates of NPP (Kenneth L. Clark, unpublished) and 4 years of monthly NEE at two Ameriflux towers in the NJPB (Clark et al. 2010). We also adjusted our decay constants (surficial soils and three SOM pools) to ensure that SOM in year 2010 was within $20 \%$ of our input data from STATSGO. Finally, we calibrated N leaching by adjusting the storm and base flow fractions (overland flow and leaching from soil profile) and calibrated dentrification by altering the fraction of nitrogen volatilization until $\mathrm{N}$ leaching losses were $<1 \mathrm{~g} \mathrm{~N} \cdot \mathrm{m}^{-2}$.year ${ }^{-1}$, in general agreement with losses in the northeastern US (Campbell et al. 2000), and dentrification rates ranged from 1 (uplands) to $2 \mathrm{~g} \mathrm{~N} \cdot \mathrm{m}^{-2}$.year-1 (wetlands), similar to published rates (Seitzinger et al. 2006).

We validated carbon dynamics using the methodology detailed in Scheller et al. (2012). Briefly, we validated modeled estimates of NPP in the uplands $\left(450 \mathrm{~g} \mathrm{C} \cdot \mathrm{m}^{-2}\right.$.year $\left.{ }^{-1}\right)$ against literature estimates of NPP ( $440 \mathrm{~g} \mathrm{C} \cdot \mathrm{m}^{-2}$.year $\left.{ }^{-1}\right)$ derived from FIA data (Pan et al. 2006 ), obtaining values that were within $25 \%$. We validated NEE using 4 years of data from a third Ameriflux tower in the NJPB (Clark et al. 2010) and obtained a significant correlation $\left(r^{2}=0.6\right)$. Our simulated SOM increased at the landscape scale over a 100-year time frame by $\sim 25 \%$, consistent with empirical observations (Kelly et al. 1997). Our simulated DOC stream output was only about $0.1 \mathrm{~g} \mathrm{C} \cdot \mathrm{m}^{-2} \cdot$ year $^{-1}$, an order of magnitude lower than field sites in the northeastern US (Campbell et al. 2000). That said, empirical estimates of DOC losses are only a small percentage of C fluxes ( $1 \%$ of ANPP).

\section{Description of the Dynamic Fire and Dynamic Biomass Fuels extensions}

We used the Dynamic Fire and Dynamic Biomass Fuels extensions to simulate wildfire effects on mortality, production, and $\mathrm{N}$ cycling (Sturtevant et al. 2009). The Dynamic Fire extension combines fuel type (e.g., ignition rates, crown: base height, spread rate under variable weather conditions) with climate and topographic information to determine the probability of wildfire ignition and spread. The Dynamic Biomass Fuels extension calculates fuel type based on tree species biomass. Together these extensions determine wildfire intensity that, when combined with species fire tolerances (table 1 in Scheller et al. 2011b), dictates cohort mortality and the amount of litter and coarse woody biomass consumed by fire. The fire regime with climate change was mechanistically simulated through altered fire weather conditions such that the effects of fire were an emergent property of climate and current levels of fragmentation.

We described our fire regime parameterization in previous publications (Scheller et al. 2008, 2011b, 2012), but briefly, we divided the landscape into eight fire regions representing both ignition and spread using an extensive database of fire occurrence and fire sizes going back to 1929 (I. La Puma, unpublished data). We de- fined eight fuel types (conifer wetland, hardwood wetland, mixed forest, pine forest, pine plains, open grass, oak forest, mixed wetland, and young upland scrub) based on the classification scheme developed by Scott and Burgan (2005), as described in Scheller et al. 2012.

Though we utilized monthly climate data for the Century extension (described above), we also needed daily climate data to run the fire extension. For the baseline scenario, weather data were obtained from the meteorological station at the Atlantic City International Airport. To generate daily data from the monthly climate change projections, we used the LARS-WG weather generator (Semenov and Barrow 1997). The simulated daily data showed good agreement in the temperature and periodicity of wet and dry spells, though a bias correction for the magnitude of the precipitation was required to match the monthly data from the GCM (details in Scheller et al. 2012). Because wind speed and wind direction were not standard outputs of GCMs when this study was conducted, we assumed that these parameters would not vary with climate change. Other fire inputs (e.g., fire weather index and buildup index) (Sturtevant et al. 2009) were derived using standard equations from the Canadian Forest Fire Weather Index System (Van Wagner 1987). Relationships between the combustion fraction of litter and wood as a function of fire severity (Scheller et al. 2008) were derived from empirical data at the site (Clark et al. 2009). Finally, slope and azimuth maps were generated from a $30 \mathrm{~m}$ resolution digital elevation model from the USGS National Elevation Dataset (http://ned.usgs.gov).

We used an iterative process to calibrate and validate the Dynamic Biomass Fuels extension (e.g., Syphard et al. 2011). We ran the model for a single 5-year time step and compared the resultant fuels map with an existing Fire Behavior Fuel Model (FBFM) map (John Hom, unpublished data) to identify areas of misclassification (Scheller et al. 2012). We repeated this process until the modeled fuels best matched the FBFM fuels map.

To validate our wildfire simulations run at a 5-year time step, we compared fire ignition rates and mean fire size between empirical data and our modeled fire in each of eight fire regions, delineated based on historic fire occurrence and fire size back to 1929 (described in detail in Scheller et al. 2011b). In all of the fire regions, simulated fire ignition rates and fire size were within one standard deviation (calculated from five model replicates) of empirical estimates (Scheller et al. 2011b). Also, the fuel type rate of spread was similar between the FBFM (Scott and Burgan 2005) and the Dynamic Fire extension, with an $r^{2}$ ranging from 0.6 to 0.9 . Ultimately, the simulated fire regime under the baseline scenario resulted in many low-severity fires and a few high-severity fires, with a fire rotation period ( $\sim 187$ years) comparable to the current fire management in the NJPB (scenario B in Scheller et al. 2008).

\section{Assessing the importance of $\mathrm{N}$ in limiting tree growth}

To estimate how much $\mathrm{N}$ limits the response of the vegetation to climate change, we compared $\mathrm{N}$ availability and carbon cycling with and without $\mathrm{N}$ limitation. The Century Succession extension tracks $\mathrm{N}$ demand, retranslocation, and uptake of each cohort (Scheller et al. 2012). These fluxes are used to compute the $\mathrm{N}$ limitation factor: $\mathrm{N}$ limitation $=(\mathrm{N}$ retranslocation $+\mathrm{N}$ uptake $) / \mathrm{N}$ demand. This $\mathrm{N}$ limitation factor (which ranges from 0 to 1 ) is then multiplied by the maximum productivity (given temperature, water, and other limitations), thereby reducing ANPP. By removing $\mathrm{N}$ limitation from the calculation of productivity (after year 0 to avoid excessive growth during spin-up), we can determine the relative importance of $\mathrm{N}$ in limiting growth.

\section{Results}

Effects of fire on mineral $\mathrm{N}$ under baseline climate

Although we expected that wildfire would decrease mineral $\mathrm{N}$ availability, our simulations indicate that fire will not affect min- 
Fig. 3. Effects of the current fire regime on mineral $\mathrm{N}$ under baseline climate in three principle land types in the NJ Pine Barrens. Each year is the average of five model replicates with corresponding standard error bars. (This figure is available in colour online.)

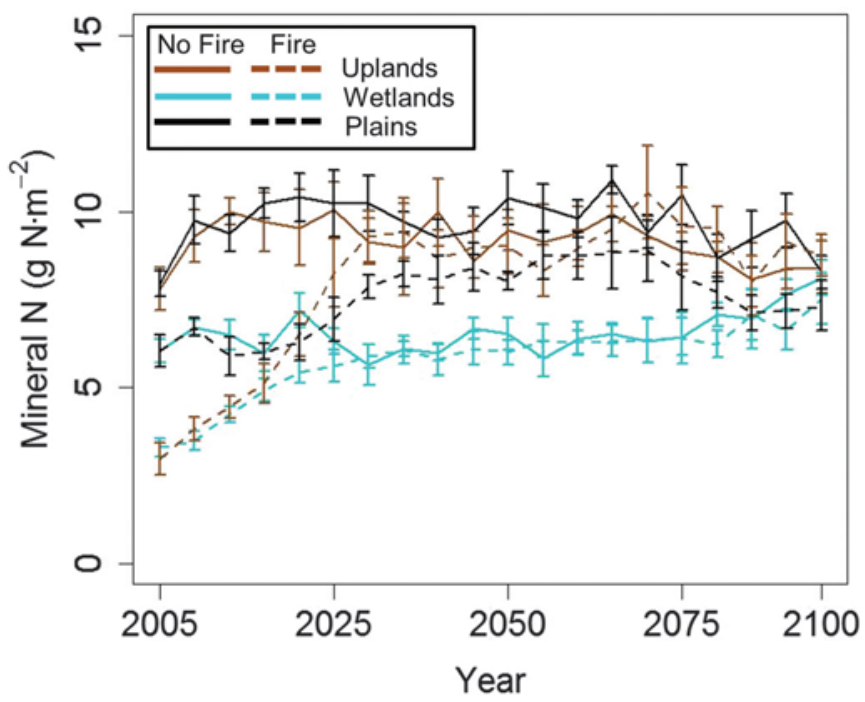

eral $\mathrm{N}$ over the long term under our current climate (Fig. 3). This occurred despite fire initially causing a dramatic decrease in mineral $\mathrm{N}$ in the uplands and wetlands. Because $\mathrm{N}$ deposition was nearly identical between fire scenarios (1.082 without fire vs. $1.083 \mathrm{~g} \mathrm{~N} \cdot \mathrm{m}^{-2}$.year ${ }^{-1}$ with fire) and $\mathrm{N}$ leaching was only $10 \%$ higher with fire ( 0.9 vs. $0.96 \mathrm{~g} \mathrm{~N} \cdot \mathrm{m}^{-2} \cdot$ year $\left.^{-1}\right)$, the differences in mineral $\mathrm{N}$ observed were due to changes in $\mathrm{N}$ uptake and mineralization. In the uplands, mineral $\mathrm{N}$ was reduced with fire due to higher $\mathrm{N}$ uptake (Fig. 4a) and lower $\mathrm{N}$ mineralization (Fig. $4 b$ ). In the wetlands, fire reduced $\mathrm{N}$ mineralization (Fig. $4 b$ ) but had little effect on uptake (Fig. $4 a$ ). In the plains, fire decreased $\mathrm{N}$ mineralization and mineral $\mathrm{N}$.

\section{Effects of fire and climate change on mineral $\mathbf{N}$}

As predicted, simulated fire under climate change (hereafter "fire and climate change" is referred to simply as climate change) reduced $\mathrm{N}$ availability by $8 \%$ across all the regions over the course of 100 years (Fig. 5). Though the change in mineral $N$ over 100 years was small, climate change had a large effect on $\mathrm{N}$ availability in the last 50 years of the simulation in the uplands and plains. After year 2050 , mineral $\mathrm{N}$ declined by $36 \%$ in the uplands and by $19 \%$ in the plains with climate change by the end of the simulation. Climate change had no impact on mineral $\mathrm{N}$ in the wetlands. These changes in mineral $\mathrm{N}$ under climate change were primarily due to increased temperature and precipitation and not changes in the fire regime; previous work in the NJPB showed that climate change did not affect fire severity or area burned (Scheller et al. 2012).

Of all of the fluxes that could affect mineral $\mathrm{N}$ (e.g., $\mathrm{N}$ deposition, mineralization uptake), climate change had the largest effects on leaching. Leaching was two-fold higher with climate change across all land types (Fig. 6a). Although leaching was consistently lowest in the wetlands, leaching was more affected by climate change in the wetlands (three-fold higher under scenario A2) than in the uplands and plains, which were only two-fold higher with climate change. These increases in leaching well exceeded the higher rates of $\mathrm{N}$ deposition that occurred with climate change, which increased from 1.08 to $1.28 \mathrm{~g} \mathrm{~N} \cdot \mathrm{m}^{-2}$.year ${ }^{-1}$ due to higher precipitation under climate change. Mineralization was higher with climate change in all land types at the end of the simulation (Fig. 6b). However, the effect was relatively small (3\%)
Fig. 4. Effects of the current fire regime on $\mathrm{N}$ uptake and $\mathrm{N}$ mineralization under baseline climate in three principle land types in the NJ Pine Barrens. Each year is the average of five model replicates with corresponding standard error bars. (This figure is available in colour online.)
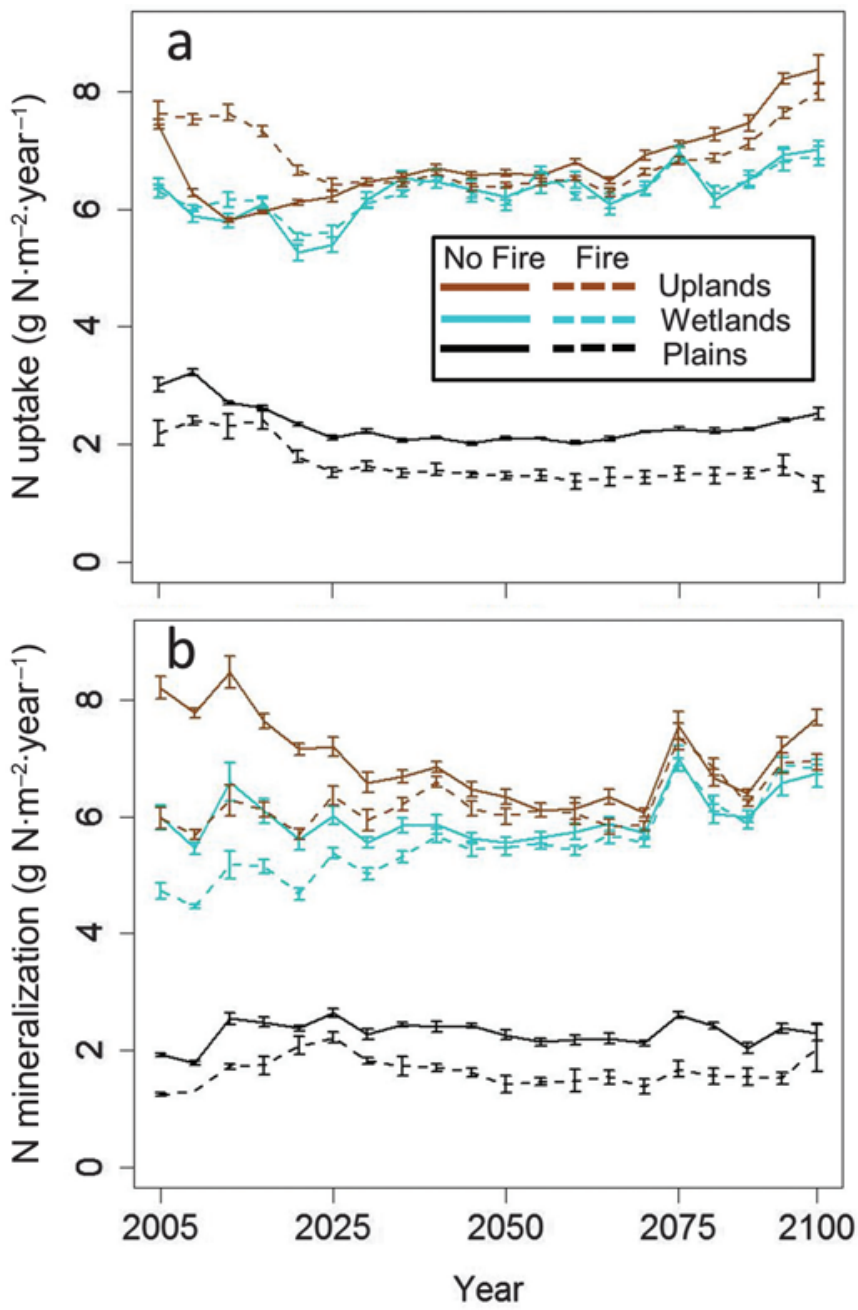

except in the plains, where $\mathrm{N}$ mineralization was $26 \%$ higher under climate change.

Climate change affected both $\mathrm{N}$ retranslocation and uptake in the upland land types but not the wetlands. Climate change increased $\mathrm{N}$ retranslocation in the uplands and wetlands in the first 15 years of the simulation (Fig. 7a), though $\mathrm{N}$ uptake increased only in the plains (Fig. 7b). By the end of the simulation, both $\mathrm{N}$ uptake and retranslocation were higher with climate change in the uplands. Climate change did not affect $\mathrm{N}$ retranslocation (Fig. $7 a$ ) or $\mathrm{N}$ uptake (Fig. $7 b$ ) in the wetlands.

\section{N limitation with fire and climate change}

When the $\mathrm{N}$ limitation was removed, tree growth under fire and climate change was higher, indicating that the trees were indeed limited by $\mathrm{N}$. In the first 50 years of the simulation, aboveground biomass was $33 \%$ higher in the uplands and about $20 \%$ higher in the wetlands when the $\mathrm{N}$ limitation was removed (Fig. 8). In the plains, biomass was only slightly $(10 \%)$ higher. When $\mathrm{N}$ was no longer limiting, tree growth rates were higher in the uplands and wetlands but only for the first 5-10 years of the simulation. In year 2005, ANPP was 400 and $325 \mathrm{~g} \mathrm{C} \cdot \mathrm{m}^{-2}$.year ${ }^{-1}$ in the uplands and wetlands, respectively. When the $\mathrm{N}$ limitation was removed, ANPP increased by $50 \%\left(600 \mathrm{~g} \mathrm{C}^{-2} \cdot \mathrm{m}^{-2}\right.$ year-1) and $23 \%\left(400 \mathrm{~g} \mathrm{C}^{-2} \cdot \mathrm{m}^{-2}\right.$ year $\left.{ }^{-1}\right)$ in 
Fig. 5. Effects of the A2 climate scenario (Hadley Community Model 3 (HadCM3) with projected changes in the fire regime) on mineral $\mathrm{N}$ in three principle land types in the NJ Pine Barrens. Each year is the average of five model replicates with corresponding standard error bars. (This figure is available in colour online.)

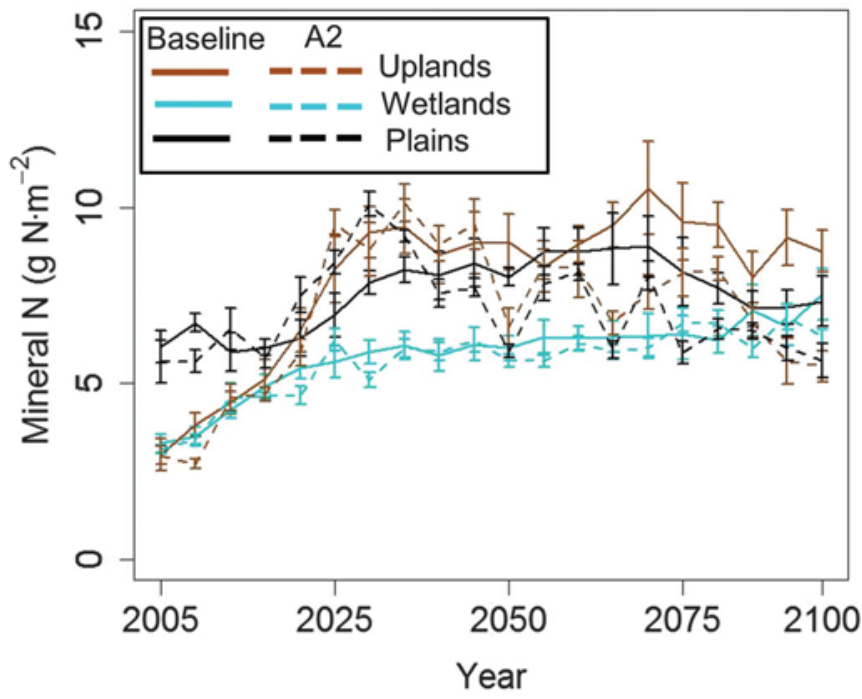

the uplands and wetlands, respectively. In the plains, ANPP was not affected by $\mathrm{N}$ limitation during those first few years of the simulation.

Over the long term (50-100 years), however, tree growth under fire and climate change was not limited by mineral N. Removing the $\mathrm{N}$ limitation had no impact on aboveground biomass (Fig. 8) or ANPP (data not shown) in any of the land types.

\section{Discussion}

We examined the potential future effects of changing climate and fire regimes on mineral $\mathrm{N}$ in the NJPB. Using this simulation approach, we found that the current fire regime may cause significant short-term $(\sim 25$ years) changes but little long-term ( $\sim 100$ years) changes in mineral $\mathrm{N}$ availability under our current climate. If the climate changes, mineral $\mathrm{N}$ availability may decline over the long term. The direction and magnitude of the changes were dependent on edaphic properties (i.e., uplands, wetlands, plains), as were the underlying mechanisms for the changes in mineral $\mathrm{N}$. Overall, the mineral $\mathrm{N}$ of soils in the NJPB is resilient to fire and climate change and is not likely to limit long-term forest growth.

In addition to validating our $C$ fluxes (described above and in Scheller et al. 2012), we compared our $\mathrm{N}$ fluxes and pools at the landscape level at the beginning of our simulation with values from the literature. Our landscape-level $\mathrm{N}$ deposition rate $\left(1.1 \mathrm{~g} \mathrm{~N} \cdot \mathrm{m}^{-2}\right.$.year $\left.{ }^{-1}\right)$ was just slightly lower than the rate currently observed in New Jersey (1.2 to $2.8 \mathrm{~g} \mathrm{~N} \cdot \mathrm{m}^{-2}$.year ${ }^{-1}$ (Gao et al. 2007). Our average $\mathrm{N}$ leaching rates $\left(0.3 \mathrm{~g} \mathrm{~N} \cdot \mathrm{m}^{-2}\right.$.year $\left.{ }^{-1}\right)$ were higher than average estimates in nearby Chesapeake Bay $\left(0.14 \mathrm{~g} \mathrm{~N} \cdot \mathrm{m}^{-2}\right.$.year ${ }^{-1}$; Stacey et al. 2000) but fell within the range of empirical observations in the region ( 0 to $0.57 \mathrm{~g} \mathrm{~N} \cdot \mathrm{m}^{-2}$.year ${ }^{-1}$ ). Our mineralization rates averaged $6 \mathrm{~g} \mathrm{~N} \cdot \mathrm{m}^{-2}$.year ${ }^{-1}$ in the uplands, while field mineralization rates at two upland sites in the NJPB ranged from 3 to $4 \mathrm{~g} \mathrm{~N} \cdot \mathrm{m}^{-2}$.year ${ }^{-1}$ (Poovarodom et al. 1988). Our simulated pool of mineral nitrogen was $3 \mathrm{~g} \cdot \mathrm{m}^{-2}$, while empirical estimates averaged $2 \mathrm{~g} \cdot \mathrm{m}^{-2}$ at two upland sites. Finally, similar rates of $\mathrm{N}$ mineralization and uptake but lower rates of $\mathrm{N}$ leaching over a 350-year period were obtained when the Century Succession extension was compared with other biogeochemical models (e.g., Biome BGC, PnET-CN) in simulated aspen stands harvested on a 50-year rotation period (Wang et al. 2014).
Fig. 6. $\mathrm{N}$ leaching and $\mathrm{N}$ mineralization for baseline (with current fire regime) and $\mathrm{A} 2$ climate change scenario (derived from the Hadley Community Model 3 (HadCM3) with projected changes in the fire regime) in three principle land types in the NJ Pine Barrens. Each year is the average of five model replicates with corresponding standard error bars. (This figure is available in colour online.)

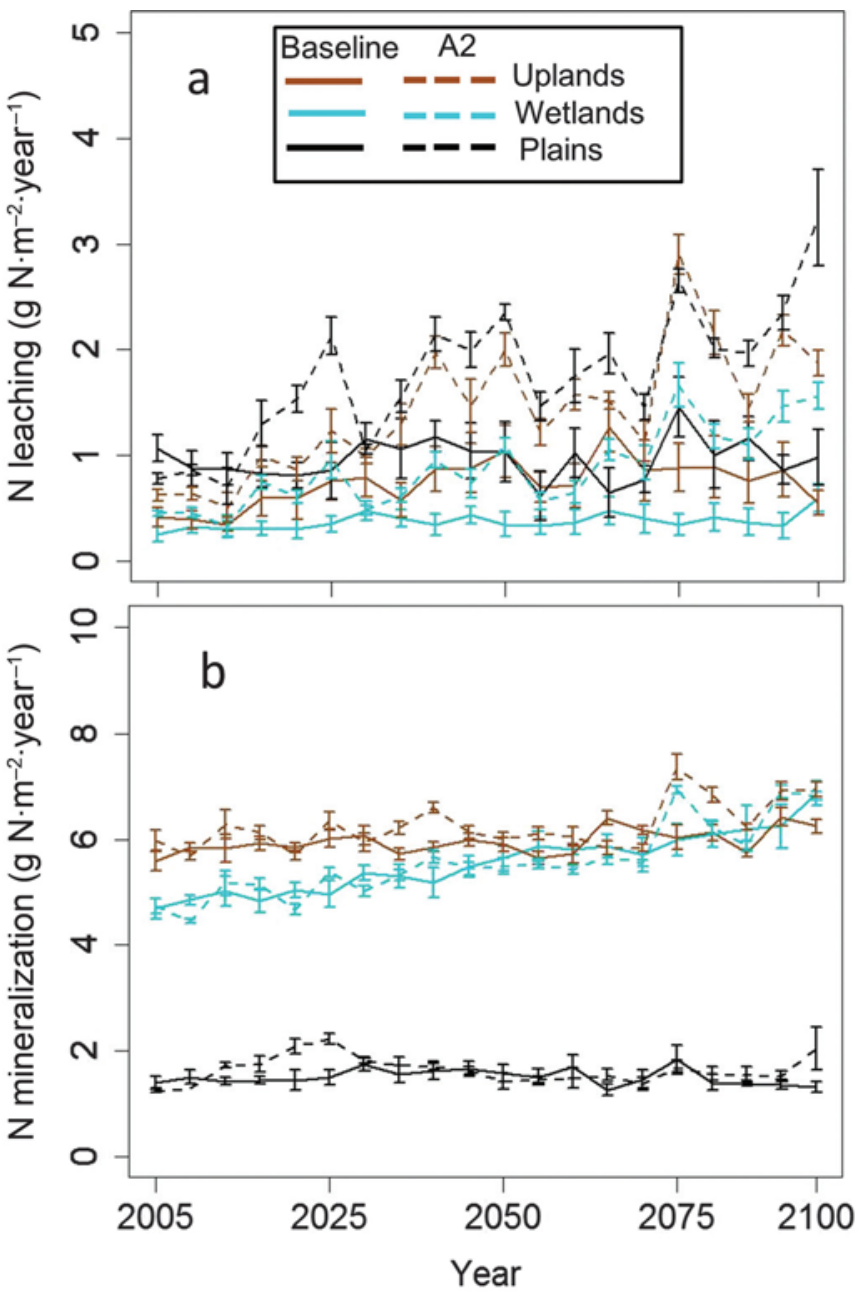

In our study, fire caused a decline in mineral $\mathrm{N}$ over the first 25 years across all soil types in our simulations. This decline is similar to those observed in stand-level field studies in mixed ponderosa pine stands (Durán et al. 2009) and shrublands (Carreira et al. 1994) over similar time frames (13-20 years). Several processes may contribute to the decline in $\mathrm{N}$ availability (after the initial pulse of $\mathrm{N}$ dissipates), including increased uptake stimulated by understory regrowth of shrubs and trees after fire (Covington et al. 1991) and decreased mineralization due to the loss of labile soil organic carbon, N stocks, or microbial biomass (Rundel 1983). We found that the relative responsiveness to fire differed with soil type. Regrowth of vegetation was important in soils with low soil water holding capacity (e.g., uplands), whereas $\mathrm{N}$ mineralization was the driver in soils with high water holding capacity (e.g., wetlands).

Though our results suggest that $\mathrm{N}$ availability will decline over the next 25 years, they also suggest that $\mathrm{N}$ availability may not be affected by fire over a longer time frame, i.e., 100 years. Our data contradict the results of the first (and only) study to examine how frequent low-intensity burning every 30 years affects long-term $\mathrm{N}$ availability. In the mixed ponderosa forests of Montana and Idaho, fires caused an increase in mineral $\mathrm{N}$ availability measured in the field over a 69- to 130-year period (DeLuca and Sala 2006). 
Fig. 7. $\mathrm{N}$ retranslocation and uptake for baseline (with current fire regime) and A2 climate scenario (Hadley Community Model 3 (HadCM3) with projected changes in fire regime) in three principle land types in the NJ Pine Barrens. Each year is the average of five model replicates with corresponding standard error bars. (This figure is available in colour online.)
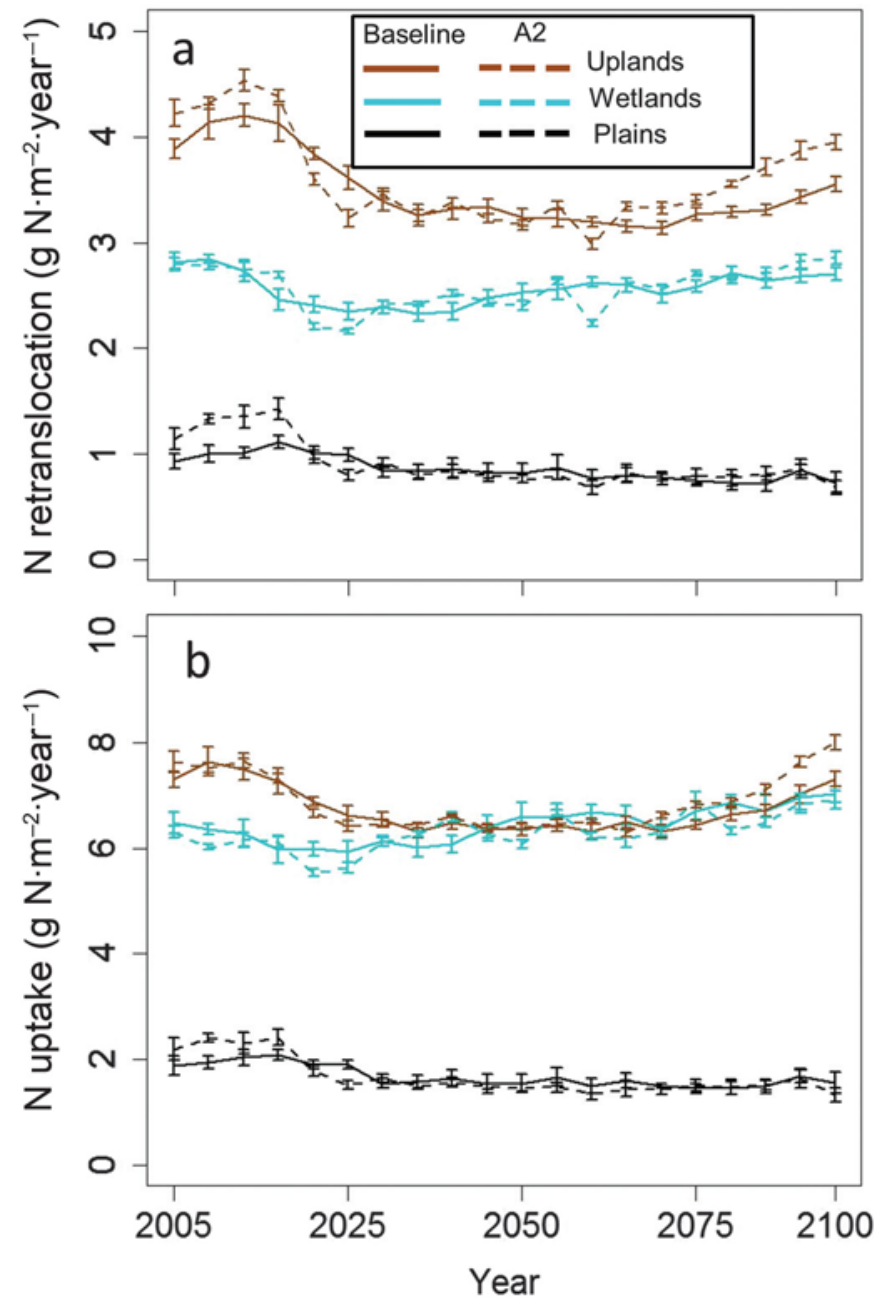

Though the results are contradictory and the studies differ in scale and species composition, together these studies indicate that ecosystems adapted to fire may be more resilient to fire over the long term ( $>25$ years) than short-term studies would indicate. Over the long term, fire-prone systems such as the NJPB have vegetation and microbes that can recover from fire, consistent with our observations of rising $\mathrm{N}$ uptake and mineralization over time.

Simulated changes in climate (in concert with fire) reduced $\mathrm{N}$ availability, though the responses differed among soil types. A previous study in the NJPB observed that climate change had little effect on fire severity and area burned (Scheller et al. 2012); therefore, we attribute the changes in $\mathrm{N}$ availability to climate change rather than fire. Climate change reduced $\mathrm{N}$ availability in the uplands and pine plains over the 100-year simulation but not in the wetlands. Our previous work showed that wetland species in the NJPB have lower growth rates under climate change, showing more sensitivity to water limitation than upland species (Scheller et al. 2012). Water limitation may play a key role in limiting climate change responses (Pastor and Post 1988), in terms of reducing both $\mathrm{N}$ uptake (this paper) and biomass (Scheller et al. 2012). However, the model has not been extensively tested in wetland
Fig. 8. Effects of $\mathrm{N}$ limitation on aboveground biomass under the A2 climate scenario (Hadley Community Model 3 (HadCM3) with projected changes in fire regime) in three principle land types in the NJ Pine Barrens. Each year is the average of five model replicates with corresponding standard error bars. (This figure is available in colour online.)

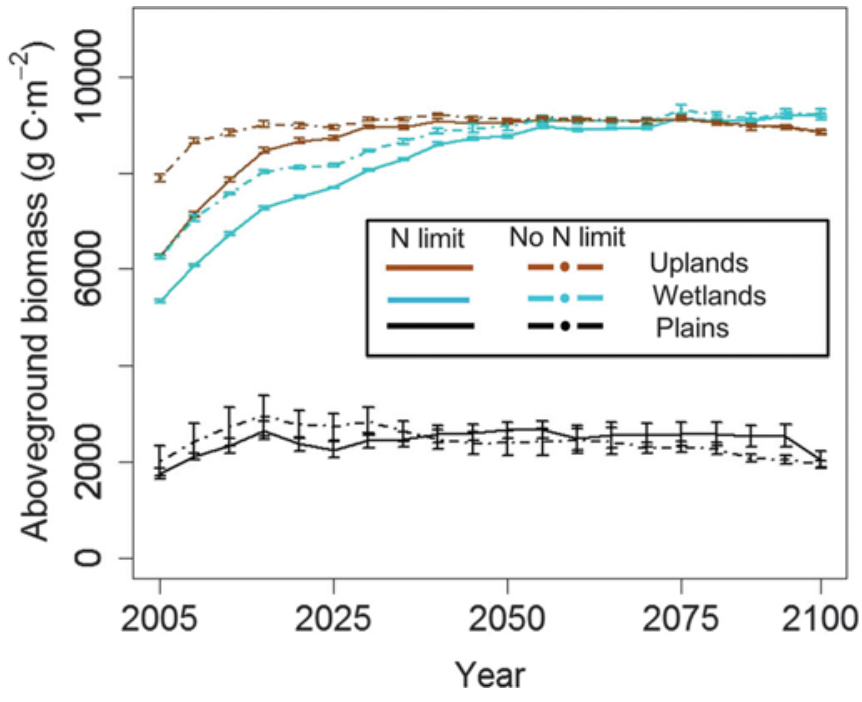

forests, and as no flux tower is positioned in NJPB wetland forests, we were unable to calibrate the $C$ dynamics of this forest type. In the uplands, climate change reduced $\mathrm{N}$ availability after 50 years, coinciding with a large increase in ANPP (Scheller et al. 2012) and $\mathrm{N}$ uptake. The ecosystem also shifted from a pine- to an oakdominated landscape (Scheller et al. 2012), though changes in litter quality and quantity appeared to have little impact on $\mathrm{N}$ mineralization. These results suggest that temporal trends in productivity (and therefore $\mathrm{N}$ uptake and retranslocation) and species composition may be the primary determinant of changes in mineral $\mathrm{N}$.

As in previous studies, our results suggest that rising temperature associated with climate change increases $\mathrm{N}$ leaching (Campbell et al. 2009), mineralization (Melillo et al. 2011; Rustad et al. 2001), and uptake due to higher temperatures (Chapin et al. 1986) and longer growing seasons (Iverson and Prasad 2002). Though the individual $\mathrm{N}$ fluxes responded to climate change with fire in a predictable manner, the relative magnitude of the changes in the fluxes was not as predicted. Leaching, uptake, and mineralization all increased with climate change, but $\mathrm{N}$ leaching increased more than uptake or mineralization. Instead, we predicted that relative stimulation of productivity (i.e., $\mathrm{N}$ uptake) or mineralization would have the greatest effect on $\mathrm{N}$ availability. In a recent field study, $\mathrm{N}$ mineralization increased by $45 \%$ over a 7-year period with a $5{ }^{\circ} \mathrm{C}$ increase in soil temperature (Melillo et al. 2011 ), but we only observed a $\sim 15 \%$ increase when we simulated a $7{ }^{\circ} \mathrm{C}$ increase in temperature over a 100-year period (Scheller et al. 2012). Large increases in $\mathrm{N}$ leaching with climate change occurred even in the wetlands, which had poor drainage. The magnitude of the changes in the fluxes $(15 \%-50 \%)$ was also surprising given that climate change had modest effects on mineral $N(\sim 10 \%)$ in the uplands and plains. The fluxes essentially cancelled each other out such that the net effect was a small change in the pool of mineral $\mathrm{N}$.

Nitrogen availability may limit response to climate change in the short term $(<50$ years) but not over the long term (50100 years). Nitrogen limited growth by $50 \%$ and $23 \%$ in the uplands and wetlands, respectively, at the start of the simulation (2005 in Fig. 8), which was consistent with our prediction. However, the limitation dissipated over time, and by 2050 , N was no longer 
limiting growth in any of the land types. Previous studies suggest that $\mathrm{N}$ may limit growth over the long term by up to $36 \%$ (Hungate et al. 2003), though that estimate was developed at the global scale. In our study, we addressed changes in internal cycling (i.e., $\mathrm{N}$ mineralization, retranslocation, and uptake), while Hungate et al (2003) only considered inputs and outputs. Though our results are specific to the NJPB, they suggest that the $\mathrm{N}$ limits growth by only $12 \%$ and $5 \%$ in the uplands and wetlands, respectively, over the next 50 years and negligibly over the next 100 years. Also, $\mathrm{N}$ did not limit growth in the plains, suggesting that the pine plains may be limited more by factors (e.g., water) other than $\mathrm{N}$ (Scheller et al. 2012).

Climate change predictions that do not consider $\mathrm{N}$ limitation may underestimate short-term but not long-term productivity responses to climate change. The decreasing importance of $\mathrm{N}$ limitation with time is analogous to the $\mathrm{CO}_{2}$ fertilization effect whereby the effect is only transient (Oechel et al. 1994) and declines over time as other factors become limiting (Luo et al. 2004; Norby et al. 2010). Though $\mathrm{N}$ may indeed limit tree growth with climate change over the short term ( $~ 25$ years), it may be a temporary limitation, the importance of which dissipates over long time frames ( $\sim 100$ years). Similarly, de Vries and Posch (2011) predicted that climate change may be a more important driver than $\mathrm{N}$ deposition in the forests of the future. In our study, rising precipitation increased $\mathrm{N}$ deposition rates by $30 \%$ over the century, which may exceed the $\mathrm{N}$ demands of the vegetation, especially given the high atmospheric deposition rates in New Jersey, which currently range from 1.2 (Gao et al. 2007) to $1.8 \mathrm{~g} \mathrm{~N} \cdot \mathrm{m}^{-2}$.year ${ }^{-1}$ (Zhang et al. 2012). Because there are strong feedbacks between disturbance, climate, and vegetation in the model, modest shifts in the climate and fire regimes result in compositional shifts, in this case towards more oak-dominated forests (Scheller et al. 2012). This has the effect of dampening the longer term climatedisturbance signal on productivity, despite the rising temperatures and precipitation associated with climate change.

As with any modeling study, our simulations were based on a number of assumptions. For example, we did not address the impacts of $\mathrm{CO}_{2}$ on $\mathrm{N}$ availability. Rising $\mathrm{CO}_{2}$ is expected to increase tree growth and water use efficiency and therefore might cause further declines in $\mathrm{N}$ availability and greater $\mathrm{N}$ limitation (Luo et al. 2004). Efforts are underway to incorporate the $\mathrm{CO}_{2}$ fertilization effect into the Century Succession extension of LANDIS-II. Also, we assumed that $\mathrm{N}$ deposition was solely a function of precipitation and that $\mathrm{CO}_{2}$ and ozone concentrations were constant. If $\mathrm{N}$ deposition in New Jersey starts to decline, as has been observed in much of the northeastern US over the past 10 years (www.epa.gov) and if $\left[\mathrm{CO}_{2}\right]$ continues to increase forest growth by $14 \%-23 \%$ (Norby et al. 2005), then our simulations may be underestimating future declines in mineral $\mathrm{N}$ with climate change. We tried to be conservative in our estimate of $\mathrm{N}$ deposition such that our average rate $\left(1.1 \mathrm{~g} \mathrm{~N} \cdot \mathrm{m}^{-2}\right.$.year $\left.{ }^{-1}\right)$ was at the low end of the range currently observed in New Jersey (1.2 to $2.8 \mathrm{~g}$ $\mathrm{N} \cdot \mathrm{m}^{-2}$.year ${ }^{-1}$; Gao et al. 2007). We also did not consider limitations by nutrients other than $\mathrm{N}$, which may limit forest responses to fire and climate change (de Vries and Posch 2011). Finally, in this study we were only quantifying changes in mineral $\mathrm{N}$ due to fire, though studies indicate that nitrate and ammonium may respond differently to fire (DeLuca and Sala 2006).

In conclusion, the mineral $\mathrm{N}$ of soils in the NJPB was resilient to fire under our current climate but declined with climate change over the long term. Our results also suggest that climate change predictions that do not consider $\mathrm{N}$ limitation may underestimate short-term but not long-term productivity responses to climate change. Together these results illustrate that declines in $\mathrm{N}$ availability are not necessarily indicative of $\mathrm{N}$ limitation and highlight the importance of simulating multiple processes (e.g., successional changes in species composition, fire, $\mathrm{N}$ uptake, decomposition) to determine the overall effect on $\mathrm{N}$ dynamics and forest productivity. Though many previous studies focus on how $\mathrm{N}$ limitation changes with rising $\mathrm{CO}_{2}$ (e.g., Luo et al. 2004), our results demonstrate the importance of including $\mathrm{N}$ dynamics when simulating the effects of temperature and precipitation, particularly in fire-prone regions such as the NJPB.

\section{Acknowledgements}

Funding was provided by the Forest Health Monitoring Plan (NE-F-0-01 and NE-F-08-01).

\section{References}

Burns, R.M., and Honkala, B.H. 1990. Silvics of North America: 1. Conifers; 2. Hardwoods. USDA Forest Service, Washington, D.C., Agriculture Handbook No. 654

Campbell, J., Hornbeck, J., McDowell, W., Buso, D., Shanley, J., and Likens, G. 2000. Dissolved organic nitrogen budgets for upland, forested ecosystems in New England. Biogeochemistry, 49(2): 123-142. doi:10.1023/A:1006383731753.

Campbell, J.L., Rustad, L.E., Boyer, E.W., Christopher, S.F., Driscoll, C.T., Fernandez, I.J., Groffman, P.M., Houle, D., Kiekbusch, J., Magill, A.H., Mitchell, M.J., and Ollinger, S.V. 2009. Consequences of climate change for biogeochemical cycling in forests of northeastern North America. Can. J. For. Res. 39(2): 264-284. doi:10.1139/X08-104.

Carreira, J.A., Niell, F.X., and Lajtha, K. 1994. Soil nitrogen availability and nitrification in Mediterranean shrublands of varying fire history and successional stage. Biogeochemistry, 26(3): 189-209. doi:10.1007/BF00002906.

Chapin, F.S., III, Van Cleve, K., and Tryon, P.R. 1986. Relationship of ion absorption to growth rate in taiga trees. Oecologia, 69: 238-242. doi:10.1007| BF00377628.

Clark, K., Skowronski, N., Hom, J., Duveneck, M., Pan, Y., Van Tuyl, S., Cole, J., Patterson, M., and Maurer, S. 2009. Decision support tools to improve the effectiveness of hazardous fuel reduction treatments. Int. J. Wildland Fire, 18: 268-277. doi:10.1071/WF08080.

Clark, K.L., Skowronski, N., and Hom, J. 2010. Invasive insects impact forest carbon dynamics. Glob. Change Biol. 16: 88-101. doi:10.1111/j.1365-2486.2009. 01983.x.

Covington, W.W., DeBano, L.F., and Huntsberger, T.G. 1991. Soil nitrogen changes associated with slash pile burning in pinyon-juniper woodlands. For. Sci. 37(1): 347-395.

de Vries, W., and Posch, M. 2011. Modelling the impact of nitrogen deposition, climate change and nutrient limitations on tree carbon sequestration in Europe for the period 1900-2050. Environ. Pollut. 159(10): 2289-2299. doi:10. 1016/j.envpol.2010.11.023.

Debano, L.F., and Conrad, C.E. 1978. The effect of fire on nutrients in a chaparral ecosystem. Ecology, 59(3): 489-497. doi:10.2307/1936579.

DeBell, D.S., and Ralston, C.W. 1970. Release of nitrogen by burning light forest fuels. Soil Sci. Soc. Am. J. 34: 936-938. doi:10.2136/sssaj1970. 03615995003400060033x.

DeLuca, T.H., and Sala, A. 2006. Frequent fire alters nitrogen transformations in ponderosa pine stands of the inland northwest. Ecology, 87: 2511-2522. doi: 10.1890/0012-9658(2006)87[2511:FFANTI]2.0.CO;2.

Durán, J., Rodríguez, A., Fernández-Palacios, J., and Gallardo, A. 2009. Changes in net $\mathrm{N}$ mineralization rates and soil $\mathrm{N}$ and $\mathrm{P}$ pools in a pine forest wildfire chronosequence. Biol. Fertil. Soils, 45(7): 781-788. doi:10.1007/s00374-0090389-4.

Forman, R.T.T., and Boerner, R.E. 1981. Fire frequency and the Pine Barrens of New Jersey. Bull. Torrey Bot. Club, 108: 34-50.

Gao, Y., Kennish, M.J., and Flynn, A.M. 2007. Atmospheric nitrogen deposition to the New Jersey coastal waters and its implications. Ecol. Appl. 17(5): S31-S41. doi:10.1890/05-1124.1.

Hafner, S.D., and Groffman, P.M. 2005. Soil nitrogen cycling under litter and coarse woody debris in a mixed forest in New York State. Soil Biol. Biochem. 37(11): 2159-2162. doi:10.1016/j.soilbio.2005.03.006.

Hungate, B.A., Dukes, J.S., Shaw, M.R., Luo, Y., and Field, C.B. 2003. Nitrogen and climate change. Science, 302(5650): 1512-1513. doi:10.1126/science.1091390.

Intergovernmental Panel on Climate Change. 2007. Climate change 2007: impacts, adaptation and vulnerability. Contribution of Working Group II to the Fourth Assessment Report of the Intergovernmental Panel on Climate Change. Cambridge University Press, Cambridge, UK.

Iverson, L.R., and Prasad, A.M. 1998. Predicting abundance of 80 tree species following climate change in the eastern United States. Ecol. Monogr. 68(4): 465-485. doi:10.1890/0012-9615(1998)068[0465:PAOTSF]2.0.CO;2.

Iverson, L.R., and Prasad, A.M. 2002. Potential redistribution of tree species habitat under five climate change scenarios in the eastern US. For. Ecol. Manage. 155(1-3): 205-222. doi:10.1016/S0378-1127(01)00559-X.

Kelly, R.H., Parton, W.J., Crocker, G.J., Graced, P.R., Klír, J., Körschens, M., Poulton, P.R., and Richter, D.D. 1997. Simulating trends in soil organic carbon in long-term experiments using the century model. Geoderma, 81(1-2): 7590. doi:10.1016/S0016-7061(97)00082-7.

Lathrop, R., and Kaplan, M. 2004. New Jersey land use/land cover update: 2000-2001. Available at http://www.nj.gov/dep/dsr/landuse/landuse00-01.pdf. 
Luo, Y., Su, B., Currie, W.S., Dukes, J.S., Finzi, A., Hartwig, U., Hungate, B.A., McMurtrie, R.E., Oren, R., Parton, W.J., Pataki, D.E., Shaw, M.R., Zak, D., and Field, C.B. 2004. Progressive nitrogen limitation of ecosystem responses to rising atmospheric carbon dioxide. BioScience, 54(8): 731-739. doi:10.1641/ 0006-3568(2004)054[0731:PNLOER]2.0.CO;2.

Melillo, J.M., Butler, S., Johnson, J., Mohan, J., Steudler, P., Lux, H., Burrows, E., Bowles, F., Smith, R., Scott, L., Vario, C., Hill, T., Burton, A., Zhou, Y.-M., and Tang, J. 2011. Soil warming, carbon-nitrogen interactions, and forest carbon budgets. Proc. Natl. Acad. Sci. U.S.A. 108(23): 9508-9512. doi:10.1073/pnas. 1018189108.

Mladenoff, D.J. 2004. LANDIS and forest landscape models. Ecol. Model. 180(1): 7-19. doi:10.1016/j.ecolmodel.2004.03.016.

Norby, R.J., DeLucia, E.H., Gielen, B., Calfapietra, C., Giardina, C.P., King, J.S., Ledford, J., McCarthy, H.R., Moore, D.J.P., Ceulemans, R., De Angelis, P., Finzi, A.C., Karnosky, D.F., Kubiske, M.E., Lukac, M., Pregitzer, K.S., Scarascia-Mugnozza, G.E., Schlesinger, W.H., and Oren, R. 2005. Forest response to elevated $\mathrm{CO}_{2}$ is conserved across a broad range of productivity. Proc. Natl. Acad. Sci. U.S.A. 102(50): 18052-18056. doi:10.1073/pnas.0509478102.

Norby, R.J., Warren, J.M., Iversen, C.M., Medlyn, B.E., and McMurtrie, R.E. 2010. $\mathrm{CO}_{2}$ enhancement of forest productivity constrained by limited nitrogen availability. Proc. Natl. Acad. Sci. U.S.A. 107(45): 19368-19373. doi:10.1073/ pnas.1006463107.

Oechel, W.C., Cowles, S., Grulke, N., Hastings, S.J., Lawrence, B., Prudhomme, T., Riechers, G., Strain, B., Tissue, D., and Vourlitis, G. 1994. Transient nature of $\mathrm{CO}_{2}$ fertilization in Arctic tundra. Nature, 371(6497): 500-503. doi:10.1038/ $371500 \mathrm{a} 0$

Pan, Y., Birdsey, R., Hom, J., McCullough, K., and Clark, K. 2006. Improved estimates of net primary productivity from MODIS satellite data at regional and local scales. Ecol. Appl. 16(1): 125-132. doi:10.1890/05-0247.

Pan, Y., Birdsey, R., Hom, J., and McCullough, K. 2009. Separating effects of changes in atmospheric composition, climate and land-use on carbon sequestration of U.S. Mid-Atlantic temperate forests. For. Ecol. Manage. 259(2): 151164. doi:10.1016/j.foreco.2009.09.049.

Parton, W.J., Anderson, D.W., Cole, C.V., and Steward, J.W.B. 1983. Simulation of soil organic matter formation and mineralization in semiarid agroecosystems. In Nutrient cycling in agricultural ecosystems. Edited by R.R. Lowrance, R.L. Todd, L.E. Asmussen, and R.A. Leonard. The University of Georgia, College of Agriculture Experiment Stations, Athens, Georgia, U.S.A.

Pastor, J., and Post, W.M. 1988. Response of northern forests to $\mathrm{CO}_{2}$-induced climate change. Nature, 334(6177): 55-58. doi:10.1038/334055a0.

Poovarodom, S., Tate, R.L.I., and Bloom, R.A. 1988. Nitrogen mineralization rates of the acidic, xeric soils of the New Jersey Pinelands: field rates. Soil Sci. 145(4): 257-263. doi:10.1097/00010694-198804000-00004.

Raison, R. 1979. Modification of the soil environment by vegetation fires, with particular reference to nitrogen transformations: a review. Plant Soil, 51: 73-108. doi:10.1007/BF02205929.

Rundel, P.W. 1983. Impact of fire on nutrient cycles in Mediterranean-type ecosystems with reference to chaparral. In Mediterranean-type ecosystems: the role of nutrients. Edited by F.J. Kruger, D.T. Mitchell, and J.U.M. Jarvis. Springer-Verlag, New York. pp. 192-207.

Ruosteenoja, K., Carter, T.R., Jylha, K., and Tuomenvirta, H. 2003. Future climate in world regions: an intercomparison of model-based projections for the new IPCC emissions scenarios, Finland. The Finnish Environment 644.

Rustad, L.E., Campbell, J.L., Marion, G.M., Norby, R.J., Mitchell, M.J., Hartley, A.E., Cornelissen, J.H.C., and Gurevitch, J. 2001. A meta-analysis of the response of soil respiration, net nitrogen mineralization, and aboveground plant growth to experimental ecosystem warming. Oecologia, 126: 543-562. doi:10.1007/ s004420000544.

Scheller, R.M., Domingo, J.B., Sturtevant, B.R., Williams, J.S., Rudy, A., Gustafson, E.J., and Mladenoff, D.J. 2007. Design, development, and application of LANDIS-II, a spatial landscape simulation model with flexible spatial and temporal resolution. Ecol. Model. 201(3-4): 409-419. doi:10.1016/ j.ecolmodel.2006.10.009.

Scheller, R.M., Van Tuyl, S., Clark, K., Hayden, N.G., Hom, J., and Mladenoff, D.J. 2008. Simulation of forest change in the New Jersey Pine Barrens under current and pre-colonial conditions. For. Ecol. Manage. 255: 1489-1500. doi: 10.1016/j.foreco.2007.11.025

Scheller, R.M., Hua, D., Bolstad, P.V., Birdsey, R.A., and Mladenoff, D.J. 2011a. The effects of forest harvest intensity in combination with wind disturbance on carbon dynamics in Lake States mesic forests. Ecol. Model. 222: 144-153. doi:10.1016/j.ecolmodel.2010.09.009.
Scheller, R.M., Van Tuyl, S., Clark, K.L., Hom, J., and La Puma, I. 2011b. Carbon sequestration in the New Jersey Pine Barrens under different scenarios of fire management. Ecosystems, 14: 987-1004. doi:10.1007/s10021-011-9462-6.

Scheller, R.M., Kretchun, A.M., Van Tuyl, S., Clark, K.L., Lucash, M.S., and Hom, J. 2012. Divergent carbon dynamics under climate change in forests with diverse soils, tree species, and land use histories. Ecosphere, 3(11): art110. doi: 10.1890/ES12-00241.1.

Scholze, M., Knorr, W., Arnell, N.W., and Prentice, I.C. 2006. A climate-change risk analysis for world ecosystems. Proc. Natl. Acad. Sci. U.S.A. 103(35): 1311613120. doi:10.1073/pnas.0601816103.

Scott, J.H., and Burgan, R.E. 2005. Standard fire behavior fuel models: a comprehensive set for use with Rothermel's surface fire spread model. USDA Forest Service, Rocky Mountain Research Station, Fort Collins, Colorado, Gen. Tech. Rep. RMRS-GTR-153.

Seitzinger, S., Harrison, J.A., Bohlke, J.K., Bouwman, A.F., Lowrance, R., Peterson, B., Tobias, C., and Van Drecht, G. 2006. Denitrification across landscapes and waterscapes: a synthesis. Ecol. Appl. 166(6): 2064-2090. doi:10. 1890/1051-0761(2006)016[2064:DALAWA]2.0.CO;2.

Semenov, M.A., and Barrow, E.M. 1997. Use of a stochastic weather generator in the development of climate change scenarios. Clim. Change, 35: 397-414. doi:10.1023/A:1005342632279.

Stacey, P.E., Greening, H.S., Kremer, N., Peterson, D.L., and Tomasko, D.A. 2000. Contribution of atmospheric nitrogen deposition to U.S. estuaries: summary and conclusion. In Nitrogen loading in coastal water bodies: an atmospheric perspective. Edited by R.A. Valigura, R.B. Alensander, M.S. Castro, T.P. Meyers, H.W. Paerl, P.E. Stacey, and R.E. Turner. The American Geophysical Union, Washington, D.C

Stephan, K., Kavanagh, K.L., and Koyama, A. 2012. Effects of spring prescribed burning and wildfires on watershed nitrogen dynamics of central Idaho headwater areas. For. Ecol. Manage. 263: 240-252. doi:10.1016/j.foreco.2011. 09.013.

Stephens, S.L., and Ruth, L.W. 2005. Federal forest-fire policy in the United States. Ecol. Appl. 15(2): 532-542. doi:10.1890/04-0545.

Stephens, S.L., Martin, R.E., and Clinton, N.E. 2007. Prehistoric fire area and emissions from California's forests, woodlands, shrublands, and grasslands. For. Ecol. Manage. 251(3): 205-216. doi:10.1016/j.foreco.2007.06.005.

Sturtevant, B.R., Scheller, R.M., Miranda, B.R., and Shinneman, D. 2009. Simulating dynamic and mixed-severity fire regimes: a process-based fire extension for LANDIS-II. Ecol. Model. 220: 3380-3393. doi:10.1016/j.ecolmodel.2009. 07.030.

Syphard, A.D., Franklin, J., and Keeley, J.E. 2011. Simulating the effects of frequent fire on southern California coastal shrublands. Ecol. Appl. 16(5): 17441756. doi:10.1890/1051-0761(2006)016[1744:STEOFF]2.0.CO;2.

Tedrow, J.C.F. 1986. Soils of New Jersey. Krieger Publishing Co., Malabar, Florida, U.S.A., Publication A-15134-1-82

U.S. Department of Agriculture National Cartography and GIS Center. 1994 State soil geographic (STATSGO) database. Data use information. U.S. Department of Agriculture National Cartography and GIS Center, Fort Worth, Texas, Report No. 1492.

Vadeboncoeur, M.A., Ouimette, A.P., and Hobbie, E.A. 2012. A robust method confirming organic nitrogen uptake by mycorrhizal roots in a temperate forest. In $97^{\text {th }}$ Ecological Society of America Annual Meeting, Portland, Oregon, 5-10 August 2012.

Van Wagner, C.E. 1987. Development and structure of the Canadian Forest Fire Weather Index System. Canadian Forestry Service, Ottawa, Ontario, Forestry Technical Report 35

Wang, F., Mladenoff, D.J., Forrester, J.A., Blanco, J.A., Scheller, R.M., Peckham, S.D., Keough, C., and Lucash, M. 2014. Multi-model simulations of forest harvesting effects on long-term productivity and $\mathrm{CN}$ cycling in aspen forests. Ecol. Appl. In press. doi:10.1890/12-0888.1

Westerling, A.L., Hidalgo, H.G., Cayan, D.R., and Swetnam, T.W. 2006. Warming and earlier spring increase western U.S. forest wildfire activity. Science, 313(5789): 940-943. doi:10.1126/science.1128834.

White, E.M., Thompson, W.W., and Gartner, F.R. 1973. Heat effects on nutrient release from soils under ponderosa pine. J. Range Manage. 26(1): 22-24. doi: $10.2307 / 3896875$.

Zhang, L., Jacob, D.J., Knipping, E.M., Kumar, N., Munger, J.W., Carouge, C.C., van Donkelaar, A., Wang, Y.X., and Chen, D. 2012. Nitrogen deposition to the United States: distribution, sources, and processes. Atmos. Chem. Phys. 12: 4539-4554. doi:10.5194/acp-12-4539-2012. 